The Journal of Laryngology \& Otology

http://journals.cambridge.org/JLO

Additional services for The Journal of Laryngology \& Otology:

Email alerts: $\underline{\text { Click here }}$

Subscriptions: $\underline{\text { Click here }}$

Commercial reprints: $\underline{\text { Click here }}$

Terms of use : $\underline{\text { Click here }}$

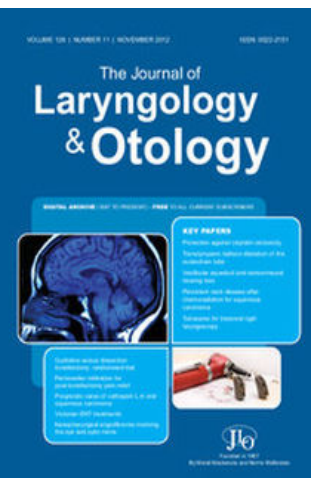

\title{
Glomus tumour of the oropharynx
}

Ricardo González-Cámpora, José Luis Villar Rodríguez, Francisco Vázquez Ramírez, Salvador Díaz Cano and Hugo Galera Ruiz

The Journal of Laryngology \& Otology / Volume 109 / Issue 01 / January 1995, pp 63 - 65

DOI: 10.1017/S0022215100129263, Published online: 29 June 2007

Link to this article: http://journals.cambridge.org/abstract_S0022215100129263

How to cite this article:

Ricardo González-Cámpora, José Luis Villar Rodríguez, Francisco Vázquez Ramírez, Salvador Díaz Cano and Hugo Galera Ruiz (1995). Glomus tumour of the oropharynx. The Journal of Laryngology \& Otology, 109, pp 63-65 doi:10.1017/ S0022215100129263

Request Permissions : $\underline{\text { Click here }}$ 


\title{
Glomus tumour of the oropharynx
}

Ricardo González-Cámpora, José Luis Villar Rodríguez, Francisco Vázquez Ramírez, Salvador díaz Cano, Hugo Galera Ruiz

\begin{abstract}
Haemangiopericytoma and glomus tumours are infrequent neoplasms in otorrhinolaryngology. A case of glomus tumour with haemangiopericytomatous features of the left amygdalar fossa is reported. Its clinical, surgical and histological features are described. This case report supports the unitary concept of smooth muscle tumours of the small vascular wall.
\end{abstract}

Key words: Oropharynx; Haemangiopericytoma; Glomus tumour

\section{Introduction}

In otorhinolaryngology, vascular tumours consisting of cells resembling the contractile cells of small blood vessel walls (haemangiopericytomas and glomus tumours) are infrequent (Walike and Bailey, 1971; Güdrün, 1979). They occur most often in the nasal cavity, paranasal sinuses, nasopharynx, and occasionally in the larynx, mouth and salivary glands ( $\mathrm{Fu}$ and Perzin, 1974; Compagno, 1978; Compagno and Hyams, 1978; Brockbank, 1979; Tajima et al., 1981; Saku et al., 1985; Allison et al., 1989; Kapadia et al., 1993; Whittam and Hellier, 1993). In the literature reviewed we found no references to these tumours in the oropharynx.

\section{Case report}

A 72-year-old woman presented with a polypoid tumour in the left amygdalar region that had been growing for seven years causing dyslalia, dyspnoea, dysphagia, and occasional bleeding on contact. On physical examination, a multilobulated tumour ( 5 $\mathrm{cm}$ maximum diameter) which was situated on the left lateral wall of the oropharynx and extended toward the midline was observed. The outer surface of the tumour was smooth with puntiform ulceration and reddish-blue colouration. The right amygdala was atrophic. Computed axial tomography (CT) showed that the tumour occupied the amygdalar fossa and extended downwards toward the piriform sinus (Figure 1). One year after total tumourectomy the patient was well and free of disease.

The surgical specimen $(5 \times 3.5 \times 3 \mathrm{~cm})$ was elastic and reddish-blue with whitish areas when seen in section. The deeper parts of the lesion were delimited by the pharyngeal aponeurosis. Histologically, the cellular proliferation was monomorphic with numerous capillary lumina and scant interstitial collagen. Large areas of the tumour had an organoid aspect and contained clear polygonal cells with round, uniform nuclei, capillaries with dilated lumina, occasional foci of hyaline struma, and clumps of polygonal cells around cavernous vascular spaces. Reticulin staining revealed a well-defined pericellular and perivascular pattern. In other areas the tumour was less differentiated and exhibited oval-shaped, poorly-defined cells arranged in compact sheets; the nuclei were oval-shaped or round and discretely pleomorphic. The vascular network in this area was prominent and consisted of elongated capillaries with a collapsed lumina. The- mitotic index in the less-differentiated area was less than 1 mitosis per 10 high magnification fields (Figure 2 ). In the organoid area, the polygonal cells were intensely and extensively immunoreactive to vimentin antibodies and exhibited focal immunostaining to specific smooth muscle actin (HHF 35) and desmin antibodies. Desmin immunostaining was always less intense and extensive than actin immunostaining and was limited to the cells of the organoid areas (Figure 3). Vessel walls included in the tumour presented specific actin and vimentin immunoreactivity. The muscular layer of venous and arterial vessels was positive for desmin. In the less-differentiated area, the oval-shaped cells with poorly-defined cytoplasm expressed only vimentin immu-

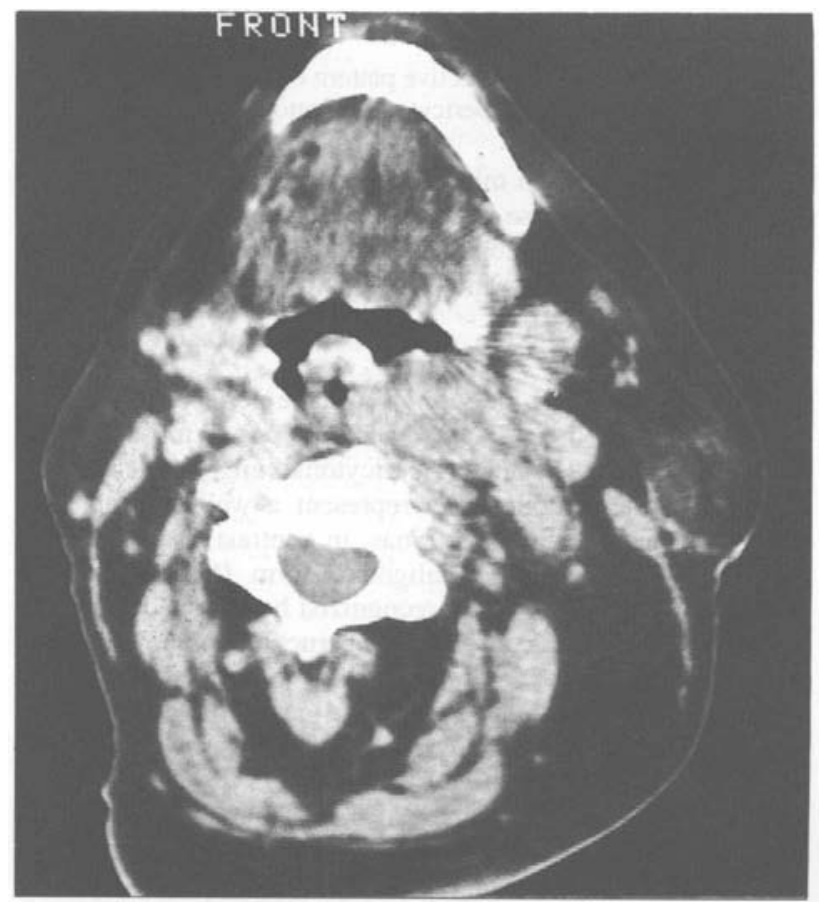

FIG. 1

CT scan showing a tumoural mass located in the left wall of the oropharynx protruding towards the midline. 


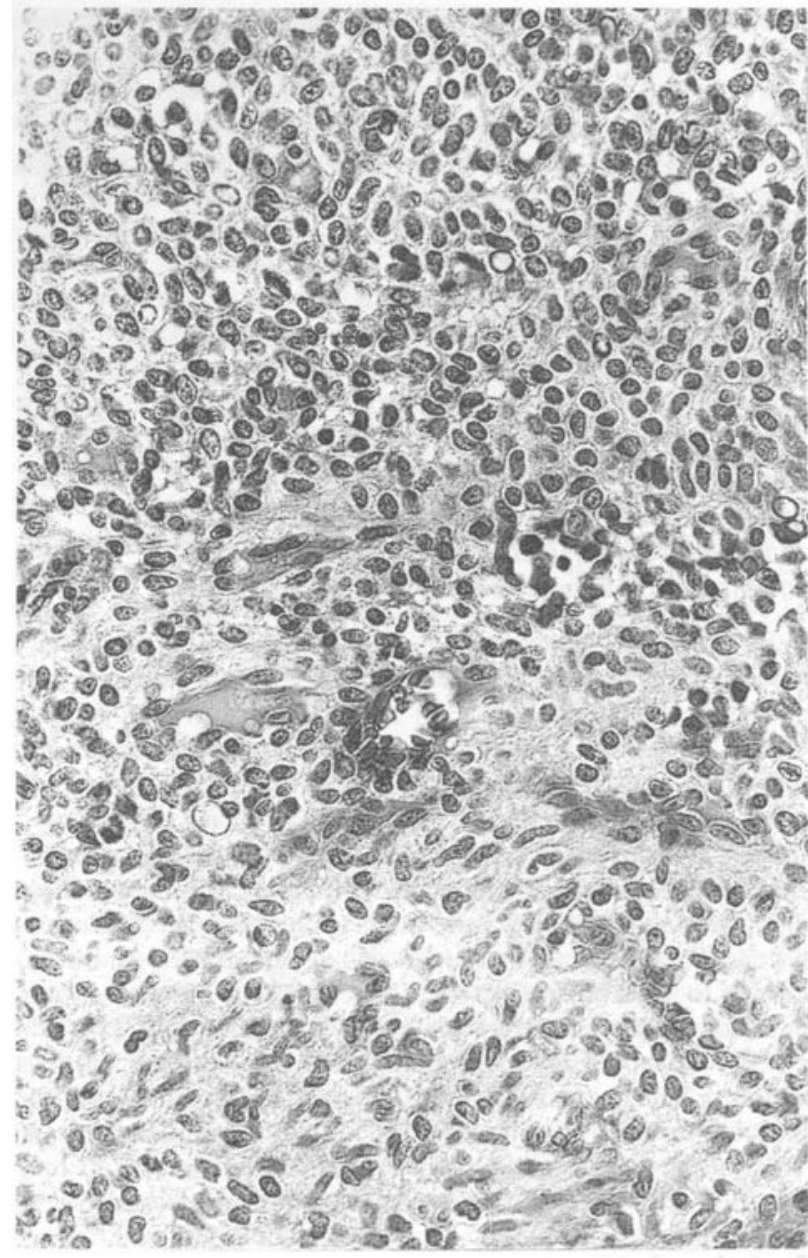

FIG. 2

Confluent area showing distinctive pattern of a glomus cell tumour

(Top) and of haemangiopericytoma (Bottom). (H\&E; $\times 200)$.

nostaining. On electron microscopy, the polygonal cells of the organoid area had dense attachment plaques, a thick basement membrane, and clear cytoplasm containing bundles of fine filaments with dense bodies and pinocytotic vesicles.

\section{Discussion}

As both the cells of the glomus and the pericytes of normal vessels express vimentin and specific smooth muscle actin, glomic tumours and haemangiopericytomas are considered to be related. Glomic tumours may represent a well-differentiated form while haemangiopericytomas, in contrast, may be a less differentiated, potentially malignant, form (Schürch et at:, 1990). The glomic tumour is recognized by its clear organioid pattern and polygonal cells with ultrastructural and immunohistochemical features of the muscle cells of Sucquet-Hoyer channels; desmin expression is inconstant and limited to a small number of cells (Nuovo et al., 1990), as in our case. Haemangiopericytomas are composed of densely packed fusiform cells immersed in a network of fine, elongated, branched capillaries; the more aggressive neoplasms contain foci of necrosis and more than four mitoses per 10 high power fields. Vascular contractile cell differentiation is not always evident, the most distinctive findings being the presence of delicate cytoplasmic prolongations surrounded by basement membrane, scant fine filaments, and pinocytotic vesicles. Immunohistochemical techniques are usually positive for vimentin only in the main cell population (Schürch et al., 1990).

Our tumour showed areas with optical, immunohistochemical, and ultrastructural findings typical of a glomic tumour in

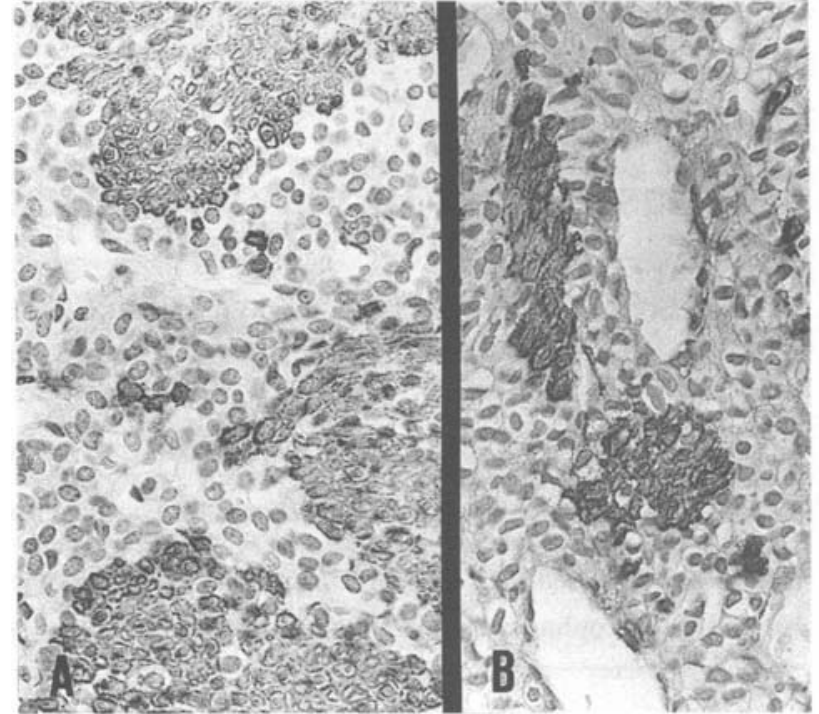

FIG. 3

Immunostaining of actin (A) and desmin (B) filaments in the polygonal cell component. (IPX; $\times 200$ ).

conjunction with less differentiated areas with haemangiopericytomatous features. This dual histological pattern has been reported in glomic tumours in other sites (Nuovo et al., 1990) and is the basis of the idea that smooth muscle tumours of the vascular wall have a common origin. Supporting this interpretation are reports of tumours with hybrid cells that express intermediate differentiation between vascular smooth muscle and pericytes (myopericytes) (Dictor et al., 1992), and of benign forms of haemangiopericytoma (haemangiopericytoma-like) that express markers of smooth muscle differentiation (Kapadia et al., 1993). These findings can be interpreted as intermediate forms on the spectrum of differentiation of these vascular muscular tumours.

\section{References}

Allison, R. S., van der Waal, I., Snow, G. B. (1989) Parapharyngeal tumours: a review of 23 cases. Clinical Otolaryngology 14: 199-203.

Brockbank, J. (1979) Hemangiopericytoma of the oral cavity: report of a case and review of the literature. Journal of Oral Surgery 37: $659-664$.

Compagno, J. (1978) Haemangiopericytoma-like tumours of the oral cavity: a comparison of haemangiopericytoma of soft tissue. Laryngoscope 88: 460-469.

Compagno, J., Hyams, J. (1978) Hemangiopericytoma-like intranasal tumours. A clinico-pathologic study of 23 cases. American Journal of Clinical Pathology 66: 672-683.

Dictor, M., Elner, A., Andersson, T., Ferno, M. (1992) Myofibromatosis-like hemangiopericytoma metastasizing as differentiated vascular smooth-muscle and myosarcoma. Myopericytes as a subset of myofibroblasts. American Journal of Surgical Pathology 16: 1239-1247.

Fu, Y.-S., Perzin, K. H. (1974) Non-epithelial tumors of the nasal cavity, paranasal sinuses, and nasopharynx: a clinicopathologic study. I: general features and vascular tumours. Cancer 33: $1275-1288$.

Güdrün, R. (1979) Haemangiopericytoma in otolaryngology. Journal of Laryngology and Otology 93: 477-494.

Kapadia, S. B., Meiss, J. M., Wenig, B. M., Frisman, D. M., Heffner, D. K. (1993) Sinonasal hemangiopericytoma. Modern Pathology 6: 81 .

Nuovo, M. A., Grimes, M. M., Knowles, D. M. (1990) Glomus tumors: a clinicopathologic and immunohistochemical analysis of forty cases. Surgical Pathology 3: 31-45.

Saku, T., Okabe, H., Matsutani, K., Sasaki, M. (1985) Glomus tumor of the cheek: an immunohistochemical demonstration of actin and myosin. Oral Surgery, Oral Medicine and Oral Pathology 60: $65-71$. 
Schürch, W., Skalli, O., Lagacé, R., Seemayer, T. A., Gabbiani, G. (1990) Intermediate filament proteins and actin isoforms as markers for soft-tissue tumor differentiation and origin. III: Hemangiopericytomas and glomus tumors. American Journal of Pathology 136: $771-786$

Tajima, Y., Neathers, D. R., Neville, B. N., Benoit, P. N., Pedley, D. M. (1981) Glomus tumour (glomangioma) of the tongue. A light and electron microscopic study. Oral Surgery 52: 288-293.

Walike, J. W., Bailey, B. J. (1971) Head and neck hemangiopericytoma. Archives of Otolaryngology 93: 345-353.

Whittam, D. E., Hellier, W. (1993) Haemangiopericytoma of the parotid salivary gland: report of a case with literature review. Journal of Laryngology and Otology 107: 1159-1 162.

Address for correspondence:

Dr Ricardo González-Cámpora,

Departamento de Anatomía Patológica,

Hospital Universitario

'Virgin Macarena',

Avda Dr. Fedriani $s / n$,

41009 Sevilla.

Spain. 